\title{
PENGUASAAN KONSEP: BERPENGARUHKAN TERHADAP KEMAMPUAN MENGAJAR?
}

\author{
Tri Candra Wulandari ${ }^{1}$, Sri Rahayu ${ }^{2}$, Yuniar Ika Putri Pranyata ${ }^{3}$ \\ ${ }^{1,3}$ Pendidikan Matematika, Universitas Kanjuruhan \\ ${ }^{2}$ Pendidikan Guru Sekolah Dasar, Universitas Kanjuruhan \\ ${ }^{1}$ fikri.chan@unikama.ac.id
}

\begin{abstract}
The aims of this study is to determine the level of correlation between the ability of concept mathematics with the ability of teaching for mathematics students in mathematics education program. Referring to the purpose, this research is a correlational research using quantitative approach on 56 students of mathematics education who are taking courses Kajian Pengembangan Matematika Sekolah 3 (KPMS3). The data obtained using the test, namely the ability of concepts mathematics test and results of teaching practice. The results of data were analyzed using Pearson Product Moment to see correlation level, while hypothesis test of this research using Independent t-test with SPSS program. Results of data processing obtained that the level of correlation is 0.133 with significance 0.173 . The result means that in this class, the ability of mathematics concept has a very low level of correlation, with meaning that the ability teaching math of students is not only influenced by the ability of mathematics concept. The result of processing data also supported by a significance level of 0.173 , which can be concluded that there is no influence between the ability of mathematics concept with the ability of teaching mathematics on mathematics students. There is a need for further research related to the readiness of prospective teachers before teaching practice in schools.
\end{abstract}

Keywords: ability of mathematics concept, ability of teaching mathematics, KPMS3

\section{Pendahuluan}

Konsep matematika diberikan kepada mahasiswa mulai semester pertama hingga semester keempat. Setelah semester keempat, mahasiswa mulai difokuskan pada kemampuan dalam pembelajaran. Kemampuan dalam pembelajaran tidak hanya terbatas pada penerapan ketrampilan dasar mengajar, akan tetapi penguasaan konsep matematika mahasiswa tetap diperhatikan selain penguasaan metode maupun model pembelajaran. Metode mengajar adalah cara guru menyampaikan materi pembelajaran dalam setiap tatap muka dengan siswa. Guru yang kreatif, profesional dituntut untuk mengembangkan pendekatan dan memilih metode mengajar yang efektif agar terjadi iklim pembelajaran yang kondusif dan menyenangkan (Maonde, 2011; Sahidin, 2013).

Peningkatan kualitas hasil belajar tidak terlepas dari faktor proses. Proses belajar mengajar merupakan salah satu faktor dominan yang mempengaruhi kualitas hasil belajar siswa dan kualitas pendidikan yang dimotori oleh guru. Guru harus benar-benar profesional dalam menjalankan tugasnya sebagai pembaharu, sebagai contoh dalam masyarakat, sebagai motor penggerak dan pendorong, sebagai pembangkit minat siswa dalam belajar siswa (Sahidin, 2013).

Kemampuan mengajar merupakan komponen yang sangat penting bagi calon guru, termasuk calon guru matematika. Calon guru diharapkan mampu menampilkan kinerja yang baik dalam menyampaikan konsep, penerapan metode pembelajaran maupun pelaksanaan proses evaluasi. Oleh karena itu, calon guru perlu dibekali dengan ketrampilan dasar mengajar, strategi dan metode pembelajaran (NSTA \& AETS, 1998 dalam Yuliati, 2007).

Berdasarkan hasil pengamatan peneliti selama melakukan pembelajaran, kemampuan mahasiswa pada konsep 
masih sangat rendah. Hal ini tampak dari ketidakmampuan mahasiswa dalam mengaitkan antar konsep. Sebagai contoh, mahasiswa kurang mampu mengaitkan konsep himpunan yang sudah pernah diperoleh pada mata kuliah Matematika Dasar 1. Akibatnya, pada saat penyajian mikro teaching mahasiswa kurang mampu menyajikan konsep dengan benar. Akan tetapi, tidak semua mahasiswa yang memiliki kemampuan pemahaman konsep kurang mampu melaksanakan praktik mengajar atau mikro-teaching dengan baik. Terkadang, mahasiswa tampak mahir menyajikan materi tertentu menggunakan metode pembelajaran tertentu, tetapi tidak menguasai konsep lainnya. Hal ini menunjukkan bahwa mahasiswa hanya mempelajari materi yang akan disajikan saja dan mengabaikan konsep lainnya.

Oleh karena itu, tujuan pada penelitian ini adalah apakah ada pengaruh besarnya pengaruh pemahaman konsep terhadap kemampuan mengajar mahasiswa calon guru matematika.

\section{Metodologi Penelitian}

Mengacu pada tujuan, maka penelitian ini merupakan penelitian korelasional dengan menggunakan pendekatan kuantitatif pada 56 mahasiswa pendidikan matematika yang sedang menempuh mata kuliah kajian pengembangan matematika sekolah 3 (KPMS3). Data yang diperoleh menggunakan tes, yaitu tes kemampuan penguasaan konsep dan hasil tes praktik mengajar. Hasil perolehan data dianalisis menggunakan pearson product moment untuk melihat tingkat korelasinya, sedangkan uji hipotesis penelitian ini menggunakan Independent t-test dengan bantuan SPSS 16.0 for Windows.

\section{Hasil dan Pembahasan}

Tes Penguasaan konsep dilaksanakan selama tiga kali, yaitu pada pertemuan pertama, pertemuan ketujuh dan pertemuan keenambelas. Skor hasil tes yang digunakan dalam analisis data merupakan rata-rata dari tiga kali tes penguasaan konsep. Hasil tes penguasaan konsep disajikan pada tabel 1 .

Tabel 1. Hasil Tes Penguasaan Konsep

\begin{tabular}{llll}
\hline \multirow{2}{*}{$\begin{array}{l}\text { Jumlah } \\
\text { Mahasiswa }\end{array}$} & $\begin{array}{l}\text { Hasil } \\
\text { Konsep }\end{array}$ & $\begin{array}{l}\text { Rata- } \\
\text { rata }\end{array}$ \\
\cline { 2 - 3 } & Min & Maks & \\
\hline 54 & 50 & 93 & 66.60 \\
\hline
\end{tabular}

Berdasarkan tabel 1 tampak bahwa hasil tes kemampuan konsep mahasiswa calon guru memiliki rata-rata 66,60 dengan skor minimal dan maksimal masing-masing adalah 50 dan 93. Berdasarkan hasil rata-rata yaitu 66, maka kemampuan konsep mahasiswa calon guru matematika berada pada grade cukup baik.

Sedangkan praktik mengajar dilaksana-kan sebanyak tiga kali praktik. Skor yang diambil merupakan skor terbaik dari keseluruhan hasil praktik mengajar. Hal ini dilakukan dengan pertimbangan bahwa kegiatan praktik mengajar membutuhkan keluwesan dan pembiasaan, oleh karena itu peneliti mengambil data skor hasil praktik mengajar merupakan skor terbaik. Hasil praktik mengajar disajikan pada tabel 2 .

Tabel 2. Hasil Praktik Mengajar

\begin{tabular}{llll}
\hline \multirow{2}{*}{$\begin{array}{l}\text { Jumlah } \\
\text { Mahasiswa }\end{array}$} & \multicolumn{2}{l}{$\begin{array}{l}\text { Hasil } \\
\text { Konsep }\end{array}$} & \multicolumn{2}{c}{$\begin{array}{l}\text { Rata- } \\
\text { rata }\end{array}$} \\
\cline { 2 - 3 } & Min & Maks & \\
\hline 54 & 50 & 94 & 71.55 \\
\hline
\end{tabular}

Berdasarkan tabel 2 tampak bahwa rata-rata skor praktik mengajar adalah 71,55 dengan skor minimal dan maksimal masing-masing adalah 50 dan 94. Secara umum, apabila kita bandingkan antara rata-rata kemampuan konsep dengan hasil praktik mengajar diperoleh bahwa rata-rata skor praktik mengajar lebih tinggi dari rata-rata skor penguasaan konsep. Meskipun demikian, penetapan apakah penguasaan konsep 
memiliki pengaruh yang signifikan dengan kemampuan mengajar mahasiswa calon guru matematika tidak diambil berdasarkan hasil rata-rata saja, peneliti masih memerlukan uji hipotesis.

Sebelum melakukan uji hipotesis dilakukan terlebih dahulu uji prasyarat yaitu uji normalitas. Uji ini dilakukan untuk mengetahui apakah data yang diperoleh berdistribusi normal atau tidak. Uji normalitas ini dilakukan dengan menggunakan bantuan SPSS 16.0 for Windows. Data yang digunakan dalam uji normalitas ini adalah data hasil tes kemampuan konsep dan skor hasil praktik mengajar. Peneliti menggunakan uji Saphiro-Wilk untuk menentukan apakah data yang diperoleh berdistribusi normal atau tidak. Data dikatakan berdistribusi normal apabila hasil signifikansi hitung yang diperoleh lebih dari 0,05 . Hasil uji normalitas disajikan pada tabel 3 .

Tabel 3. hasil uji normalitas

\begin{tabular}{lll}
\hline & grup & sig. \\
\hline \multirow{2}{*}{ Skor } & konsep & 0.06 \\
\cline { 2 - 3 } & praktik & 0.10 \\
\hline
\end{tabular}

Berdasarkan tabel 3 diperoleh bahwa signifikansi skor kemampuan konsep adalah 0,06 >0,05. Hal ini berarti data hasil tes kemampuan konsep matematika mahasiswa berdistribusi normal. Begitu juga skor yang diperoleh dari hasil praktik mengajar, hasil signifikansi hitung pada skor praktik adalah $0,10>0,05$. Hal ini menunjukkan bahwa data hasil praktik mengajar mahasiswa berdistribusi normal.

Uji prasyarat selanjutnya adalah uji homogenitas. Sama halnya dengan uji normalitas, pada uji homogenitas ini peneliti menggunakan data hasil tes kemampuan konsep dan skor hasil uji praktik. Data dikatakan homogen apabila hasil signifikansi hitung >0,05. Hasil uji homogenitas ditampilkan pada tabel 4
Tabel 4. Hasil uji homogenitas

\begin{tabular}{lll}
\hline & \multicolumn{2}{c}{ Uji Levene } \\
\cline { 2 - 3 } & F & sig \\
\hline $\begin{array}{l}\text { kesamaan varian yang } \\
\text { diasumsikan }\end{array}$ & 2.159 & 0.145 \\
\hline $\begin{array}{l}\text { kesamaan varian yang } \\
\text { tidak diasumsikan }\end{array}$ & & \\
\hline
\end{tabular}

Berdasarkan tabel 4 pada uji homogenitas tampak bahwa kesamaan varian memiliki siginifikansi $0,145>$ 0,05 . Hal ini berarti data yang diperoleh memiliki kesamaan varian atau homogen.

Berdasarkan hasil prasyarat, kedua data yang diperoleh berdistribusi normal dan homogen, sehingga proses analisis data dapat dilanjutkan menggunakan statistik parametrik menggunakan Independent sample t-tes.

Sebelum melakukan uji hipotesis, terlebih dahulu peneliti ingin melihat seberapa besar hubungan antara kemampuan konsep matematika dengan kemampuan mengajar. Oleh karena itu, peneliti akan melihat besarnya korelasi dari data hasil tes konsep dengan hasil praktik. Penentuan korelasi menggunakan teknik Pearson Correlation menggunakan bantuan SPSS 16.0 for Windows. Hasil korelasi antara hasil tes konsep dan hasil praktik mengajar disajikan pada tabel 5 .

\section{Tabel 5. Korelasi Hasil Tes Konsep} dengan Hasil Praktik

\begin{tabular}{ll}
\hline & Skor \\
\hline Korelasi Pearson & 0.133 \\
\hline sig. (2-tailed) & 0.173 \\
\hline
\end{tabular}

Berdasarkan tabel 5 tampak bahwa besarnya korelasi antara tes konsep dan praktik adalah 0,133 dengan signifikansi 0,173 . Hal ini menunjukkan bahwa hubungan antara tes konsep dengan kemampuan praktik mengajar menyatakan sangat kecil, dengan memperhatikan tingkat signifikansi sebesar 0,173 > 0,05 maka, hasil korelasi adalah valid. 
Tahap berikutnya adalah melakukan uji hipotesis. Uji hipotesis pada penelitian ini menggunakan Independent sample t-test. Berdasarkan hasil Uji-t tampak bahwa sig.(2-tailed) yang diperoleh adalah 0,173 . Hasil sig. hitung $>0,05$ hal ini berarti bahwa tidak ada pengaruh antara kemampuan konsep dengan kemampuan mengajar mahasiswa calon guru matematika.

Pada kelas Kajian Pengembangan Matematika Sekolah 3 (KPMS3) ini kemampuan konsep tidak memiliki pengaruh yang signifikan terhadap kemampuan mengajar mahasiswa calon dosen. Secara umum, unsur utama yang harus dikuasai guru adalah bagaimana ketrampilan mengajar di kelas (Alita, 2014).Mengajar merupakan aktivitas yang kompleks, menggabungkan tiga dimensi yaitu kognitif, afektif dan tingkah laku (Lynch dalam Rozimela, 2013). Berdasarkan hasil tes, tampak bahwa terdapat korelasi antara penguasaan konsep dengan kemampuan mengajar. Besarnya korelasi adalah 0.133 , meskipun nilai korelasi berada pada kategori sangat rendah, penguasaan konsep masih tampak mempengaruhi kemampuan mengajar. Rendahnya korelasi yang dihasilkan berdampak pada signifikansi yang diperoleh dengan menggunakan Independent $t$ test yaitu 0.173. signifikansi yang diperoleh $>0.05$ menunjukkan bahwa tidak ada pengaruh antara penguasaan konsep dengan kemampuan mengajar.

Kemampuan mengajar bagi mahasiswa calon guru secara mutlak tidak hanya dipengaruhi oleh penguasaan konsep saja. Karena, selain menguasai konsep, calon guru perlu menguasai unsur lainnya seperti kemampuan sosial dan ke-mampuan pedagogik. Kompetensi pedagogik merupakan kompetensi yang secara khas mencirikan dan membedakan profesi guru dengan profesi lainnya (Nur, 2014). Sejalan dengan itu, Saragih (2008) menyatakan bahwa penguasaan terhadap teori perkembangan dan teori-teori belajar mutlak ada pada guru. Kemampuan mengajar guru tampak dari terampil atau tidaknya seorang guru di kelas. Ketrampilan itu tampak dari membuka dan menutup pelajaran, bertanya, memberi penguatan, dan mengadakan variasi mengajar (Wijaya dalam Saragih, 2008). Sedangkan faktor penguasaan konsep merupakan salah satu faktor pendukung utama dalam penyampaian konsep, karena hal ini lebih mengarah pada rasa percaya diri calon guru. Kurangnya kesiapan guru (penguasaan materi kurang) sehingga timbul tidak percaya diri (Syafi'i,2014)

\section{Kesimpulan}

Berdasarkan analisis data dan pembahasan, maka dapat disimpulkan bahwa pada penelitian ini kemampuan penguasaan konsep tidak berpengaruh terhadap ketrampilan mengajar mahasiswa calon guru matematika. Hal ini tampak dari tingkat korelasi yang sangat kecil yaitu 0,133 dengan nilai signifikansi uji menggunakan Independent t-test 0,173 .

Penelitian ini hanya melihat pada korelasi pada penguasaan konsep dan kemampuan mengajar mahasiswa calon guru, oleh karena itu peneliti merekomendasikan untuk peneliti berikutnya agar melakukan penelitian terkait analisis kemampuan mengajar mahasiswa calon guru atau pengembangan rubrik penilaian mengajar sesuai dengan kurikulum yang ditetapkan sehingga program studi benar-benar siap mencetak tenaga guru matematika yang profesional.

\section{Daftar Pustaka}

Alita, D., Enawaty, E., \& Melati, H. A. 2014. Analisis Keterampilan Dasar Mengajar Guru Kimia Sma Di Pontianak Berdasarkan Kurikulum 2013. Jurnal Pendidikan dan Pembelajaran, 3(12).

Bell, Frederick. H. 1978. Teaching and Learning Mathematics

(In


Secondary School). Wm.C. Brown Company. Dubuque: Iowa.

Nur, A. A. 2014. Meningkatkan Kompetensi Pedagogik Guru di SD Yayasan Mutiara Gambut. Bahana Manajemen Pendidikan, 2(1): 6572.

Rozimela, Y. 2013. Using Reflective Teaching To Develop Student's Teaching Skills. Bahasa Dan Seni, 41(1).

Sahidin, Latif dan Jamil, Dini. 2013. Pengaruh Motivasi Berprestasi dan Persepsi Siswa Tentang Cara Guru Mengajar Terhadap Hasil Belajar Matematika. Jurnal Pendidikan Matematika, 4(2).

Saragih, A. Hasan. 2008. Kompetensi Minimal Seorang Guru dalam Mengajar. Jurnal Tabularasa UNIMED, 5(1): 23-34.

Sugiyono. 2016. Statistika untuk Penelitian. Alfabeta: Bandung

Syafi'i, M. 2014. Implikasi Pembelajaran Mikro Dalam Pengembangan Keterampilan Mengajar Di Madrasah. Religi: Jurnal Studi Islam, 5(2): 228-250.

Yuliati, Lia. 2007. Pengembangan Model Pembelajaran untuk Meningkatkan Kemampuan Mengajar Calon Guru Fisika. Jurnal Ilmu Pendidikan, 14: 32-40. 